\title{
Trace element availability from the human diet
}

\section{By Susan Southon, Susan J. Fairweather-Tait and T. Hazell, AFRC Institute of Food Research, Norwich Laboratory, Colney Lane, Norwich NR4 7UA}

Accurate compositional information on dietary components, although providing valuable information, is at best only a rough guide to the nutritional value of the diet. It has long been recognized that some nutrients are not fully absorbed and utilized in the metabolism of the individual, and that mineral nutrients in particular are subject to a wide range of complex interactions which affect their absorption and subsequent metabolism. A complete understanding of the nutritional value of the human diet therefore requires consideration of a number of dietary, physiological, and possibly genetic factors, which undoubtedly affect nutrient utilization.

In recent years the concept of nutrient availability has been seen to include many different types of measurement of nutrient utilization in animals and man, and there is an increasing tendency for the terms availability, digestibility and absorbability to be used interchangeably. A nutrient may be described as 'available' with respect to consumption, absorption or metabolism, and therefore to avoid confusion the term 'availability' should always be clearly defined within the context of each study. Ideally, a full assessment of mineral availability from a diet or food should include the measurement of total content, an estimate of the proportion of the total that is in an absorbable form (i.e. maximum theoretical), the actual amount absorbed and, finally, the proportion of the total which is utilized by the body. The most important criterion with which to judge the nutritional quality of a diet or food in terms of availability is the utilization of the nutrient for the maintenance of normal metabolic function (see Fairweather-Tait, 1987). Differences in measurements of digestibility and absorbability are, to some extent, irrelevant provided that the individual has the capacity to maintain normal body function and optimal health on a particular dietary supply.

There are large inter- and intra-subject variations in iron absorption (Cooke et al. 1969) which at present remain largely unexplained. Human subjects in Fe studies (Fairweather-Tait \& Minski, 1986) show widely differing capacities for Fe absorption from a test dose of ${ }^{58} \mathrm{FeSO}_{4}$ after an overnight fast, although they apparently have a similar Fe status. This variation is probably linked to differences in body Fe status (Cooke et al. 1974), gastric acid secretion (Jacobs et al. 1964) and to other physiological factors at the time of dosing. However, we cannot discount the possibility that mechanisms exist whereby individuals are able to respond to a variable supply of minerals from the diet by altering their absorptive capacity, or their efficiency of metabolic utilization. The ultimate measurement of mineral availability from a particular dietary source must therefore be its contribution to the maintenance of body function. Unfortunately, our knowledge of the biochemical role of many trace elements, and adequate diagnostic tests for mineral status, lag far behind this concept. Therefore, at present, we rely mainly on compositional information, coupled wherever possible with estimates of availability for absorption within groups of subjects, to determine the potential usefulness of a dietary mineral source.

\section{Factors affecting mineral availability}

Factors which affect mineral availability can be broadly divided into dietary and physiological factors (Fig. 1). However, this is to some extent an artificial separation 


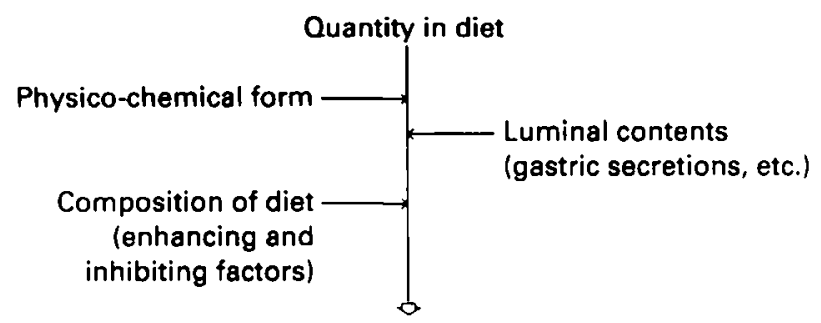

Quantity 'available' for absorption
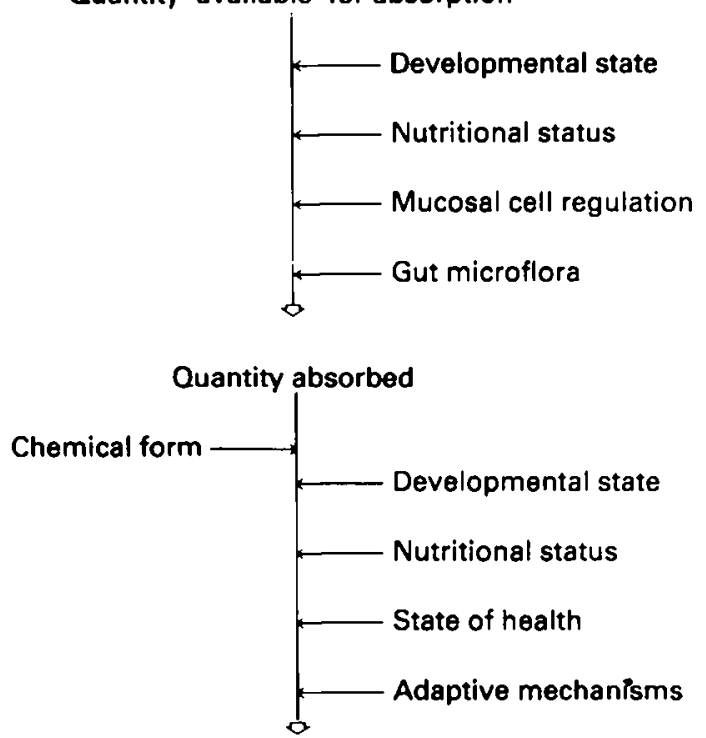

Quantity utilized

Fig. 1. Factors influencing mineral availability.

because of the close relation between the diet and the physiological response of the body.

Dietary factors. These include quantity consumed, chemical form, dietary interactions, and hence total composition of the diet. When investigating the adequacy of a diet in terms of inorganic nutrients one of the first considerations to be made is whether the total levels are sufficient. Many dietary intake studies indicate that the human diet is often suboptimal with respect to trace minerals (Casey \& Hambidge, 1980; Sandstead, 1975) when compared with the recommended daily allowances published by the Department of Health and Social Security (1979) in the UK and the National Research Council (1980) in the USA. This is illustrated by the estimated daily Fe, zinc and copper intakes for different groups of the UK population (Table 1). Values were obtained from weighed dietary intakes for variable periods (see Table 1), and mineral intakes calculated from food composition tables using values from Paul \& Southgate (1978), Wiles et al. (1980), Gopalan et al. (1984), Tan et al. (1985) and unpublished values from L. Stockley, AFRC Institute of Food Research, Norwich (IFRN), and the MRC Dunn Nutrition Unit. Calculating nutrient intakes from food composition tables, particularly inorganic constituents of the diet, is notoriously inaccurate. Nevertheless in every study the mean daily $\mathrm{Zn}$ intake was lower, and in some instances substantially lower, than the USA 
Table 1. Daily iron, zinc and copper intakes (mg) for a range of groups of different racial origins resident in the $U K$

(Mean values and standard deviations)

\begin{tabular}{|c|c|c|c|c|c|c|c|c|c|c|}
\hline \multirow[b]{2}{*}{ Group surveyed } & \multirow[b]{2}{*}{$n$} & \multirow[b]{2}{*}{ Sex } & \multirow{2}{*}{$\begin{array}{c}\text { Age } \\
\text { (years) }\end{array}$} & \multicolumn{2}{|c|}{$\mathrm{Fe}^{*}$} & \multicolumn{2}{|c|}{$\mathbf{Z n}^{*}$} & \multicolumn{2}{|c|}{$\mathrm{Cu}^{*}$} & \multirow{2}{*}{$\begin{array}{c}\text { Study } \\
\text { period (d) }\end{array}$} \\
\hline & & & & Mean & $\mathrm{SD}$ & Mean & SD & Mean & SD & \\
\hline \multirow[t]{3}{*}{ Europeans } & 22 & $d+q$ & $9-11$ & $9 \cdot 1$ & $2 \cdot 1$ & $6 \cdot 7$ & $2 \cdot 1$ & $1 \cdot 2$ & 0.4 & 5 \\
\hline & 17 & $\delta+q$ & $21-48$ & $14 \cdot 1$ & $4 \cdot 2$ & $10 \cdot 6$ & $3 \cdot 2$ & 1.8 & 0.6 & 28 \\
\hline & 20 & $\delta$ & $45-54$ & $15 \cdot 1$ & $4 \cdot 7$ & 12.5 & 3.0 & 1.9 & 0.8 & 5 \\
\hline Gujaratis & 15 & $\delta$ & $45-54$ & $15 \cdot 4$ & $6 \cdot 1$ & $7 \cdot 4$ & $2 \cdot 8$ & 1.7 & 0.6 & 5 \\
\hline West Indians & 11 & $\delta$ & $45-54$ & $18 \cdot 0$ & $7 \cdot 7$ & $12 \cdot 2$ & $3 \cdot 3$ & $2 \cdot 8$ & 2.5 & 5 \\
\hline
\end{tabular}

*Recommended dietary allowance ((US) National Research Council, 1980); Fe 9-11 years 10-18 mg, others $10 \mathrm{mg} ; \mathrm{Zn}$ 9-11 years 10-15 mg, others $15 \mathrm{mg}$; Cu 2-3 mg.

recommended level. $\mathrm{Cu}$ intakes were also lower in all but one survey. It is, of course, possible that the recommended allowances for these trace minerals are set too high, but recent findings by Black et al. (1986) also support the suggestion that intakes of $\mathrm{Zn}$ and Cu may be marginal in some groups of the population, particularly those consuming diets in the lower energy range.

The daily Fe intakes of the subjects in the surveys (Table 1) appeared to be adequate, except in the case of the 9-11-year-old children. However, a diet which appears to contain a sufficient level of a mineral may still prove inadequate in the presence of components of the diet which reduce its availability for absorption. The physico-chemical form of a mineral as it enters and passes along the digestive tract is a major determinant of its availability (Hazell, 1985). In the surveys (Table 1), the Gujarati subjects consumed 14 and $8 \%$ of their energy as chapatis and pulses respectively. Their diet would therefore be relatively high in phytate, a strong binder of minerals, particularly $\mathrm{Zn}$, and the quality of the diet with respect to minerals may therefore be adversely affected.

In vitro studies at IFRN clearly demonstrate the influence of both endogenous and added food components on $\mathrm{Fe}$ diffusibility and hence their potential effect on $\mathrm{Fe}$ absorbability. Sodium phytate, ascorbic and citric acid were added to foods containing very low levels of these substances, in amounts corresponding to natural levels in a variety of plant foods. The foods were subjected to simulated pepsin (EC 3.4.23.1)hydrochloric acid gastric digestion in the presence of ${ }^{59} \mathrm{Fe}$, followed by neutralization with sodium bicarbonate, introduced into the digesta in dialysis tubing (molecular cut-off 12000 ), using the methods described by Miller et al. (1981). Following further digestion with a pancreatin-bile extract mixture, measurement of the proportion of radioactive $\mathrm{Fe}$ passing across the dialysis tubing was used to assess Fe diffusibility from the food. As expected, increasing concentrations of phytate produced a reduction in diffusible $\mathrm{Fe}$, with a very marked reduction at the concentration most likely to be found in cereals and legumes. Conversely, the addition of ascorbate and citrate enhanced $\mathrm{Fe}$ diffusibility. Ascorbate has been described as a major determinant of $\mathrm{Fe}$ availability for absorption (Hallberg et al. 1986), but in this study it only enhanced Fe diffusibility when added in much larger amounts than those normally found in foods, whilst citrate enhanced $\mathrm{Fe}$ diffusibility at levels naturally present in many foods (Hazell \& Johnson, 1987a). 
This technique has also been used to obtain values for dialysable $\mathrm{Fe}$ in a variety of fresh and processed foods (Hazell \& Johnson, 1987b). In general, processing enhanced Fe diffusibility compared with the unprocessed food item. The reasons for this effect have yet to be determined but factors under consideration include variety, refining technique, heat treatment and, probably the most important factor, the presence of common additives such as citric, ascorbic, acetic and lactic acid, which have all been shown to enhance Fe absorption in man (Gillooly et al. 1983, 1984).

In relation to the effects of food processing, a particular area of interest at present is the influence of high-pressure, high-temperature food extrusion on mineral nutrition. Extrusion cooking is being increasingly used in the production of snack foods, and specialized weaning and slimming products; such foods are likely to make a significant contribution to the total intake of subgroups of the population who may be potentially vulnerable to mineral deficiency. During the process of extrusion cooking the combined effects of temperature, pressure and extreme shear force to which the food materials are subjected lead to major transformations in the high-molecular-weight constituents (Linko et al. 1981), which may modify the physico-chemical form and subsequent release of complexed inorganic constituents during digestion. A preliminary study was undertaken to investigate $\mathrm{Fe}$ and $\mathrm{Zn}$ absorption in rats from maize and potato extruded at high temperature $\left(120-140^{\circ}\right)$ and pressure $(500-900 \mathrm{psi})$, to give an indication as to whether this form of processing may affect mineral absorption in man (Fairweather-Tait \& Symms, 1986). Analysis of the test materials showed that there was a large increase in $\mathrm{Fe}$ content after extrusion which resulted in a doubling of the Fe concentration in both the maize and potato. The origin of this Fe was thought to be the extruder itself since there was no other procedure that could have contaminated the food. The phytate levels of the maize were halved with extrusion cooking (Fairweather-Tait et al. 1987). Following an overnight fast, rats were given a test meal of the extruded or non-extruded food made to a paste with distilled water, in amounts calculated to contain similar levels of $\mathrm{Fe}$ and $\mathrm{Zn}$. All test meals were labelled extrinsically with approximately $0.5 \mu \mathrm{Ci}{ }^{59} \mathrm{Fe}$ or $1 \mu \mathrm{Ci}{ }^{65} \mathrm{Zn}$. Immediately after consuming the meals the radioactivity in the rats was measured using a whole-body counter. The radioactivity in the Fe groups was measured again $7 \mathrm{~d}$ later and the proportion of Fe absorbed calculated as described by Fairweather-Tait \& Wright (1984). The radioactivity in the $\mathrm{Zn}$ group was measured daily for $14 \mathrm{~d}$ and the percentage retention calculated with due allowance for daily turnover (Fairweather-Tait et al. $1985 \mathrm{~b}$ ). It was found that the absorption of Fe from the extruded and non-extruded foods was similar, indicating that for these food items at least this form of processing had no adverse effect on $\mathrm{Fe}$ availability (Fairweather-Tait et al. 1987). Furthermore, the $\mathrm{Fe}$ added to the food during processing appeared to be as available for absorption as the endogenous $\mathrm{Fe}$ and could therefore prove to be a useful supplement in some circumstances. $\mathrm{Zn}$ absorption was increased with extrusion cooking, due possibly to the reduction in phytate.

Physiological factors. Physiological factors affecting mineral absorption and utilization are as wide ranging and perhaps more complex than purely dietary factors. Stage of development, nutritional status, state of health, pregnancy and lactation, and the ability of individuals to adapt to variations in nutrient supply can all influence the availability of minerals for absorption and metabolism. Obviously it is not possible to discuss all these factors in a single paper. Consequently, the following studies performed at IFRN, have been selected to illustrate the importance of such influences when considering human mineral nutrition.

It is well recognized that Fe-deficiency anaemia results in an increased capacity to absorb Fe (Bothwell et al. 1958). However, recent studies in both rats (Fairweather-Tait 
\& Wright, 1984; Fairweather-Tait et al. 1985) and man (Fairweather-Tait \& Minski, 1986) indicate that $\mathrm{Fe}$ absorption is also influenced by the level of $\mathrm{Fe}$ in the diet consumed during the previous $1-3 \mathrm{~d}$. This suggests a second more immediate pathway by which $\mathrm{Fe}$ absorption is regulated. It has been shown that in young rats, meal-fed on an adequate-Fe $(38 \mathrm{mg} / \mathrm{kg})$ semi-synthetic diet for 2 weeks, followed by diets containing 8 , $77,136,556,1270 \mathrm{mg} \mathrm{Fe} / \mathrm{kg}$ for $3 \mathrm{~d}$, Fe absorption is a function of the logarithm of dietary $\mathrm{Fe}$ concentration during the $3 \mathrm{~d}$ before the $\mathrm{Fe}$ absorption test. Experiments carried out over 1-2 d demonstrated that, in fact, only one meal in the previous $24 \mathrm{~h}$ was required to produce a similar effect (Fairweather-Tait \& Wright, 1984). Further studies in this area showed that the time-span over which this effect persisted approximated to mucosal-cell turnover time in the rat, thus indicating that mucosal cells may be important in the short-term regulation of Fe absorption (Fairweather-Tait et al. 1985a). The diet effect has been shown to operate before there is any fall in haemoglobin in rats (Fairweather-Tait \& Wright, 1986). Anaemic animals had a higher efficiency of absorption than control animals, and giving a low-Fe diet for $3 \mathrm{~d}$ enhanced the capacity of the control but not the anaemic rats to absorb Fe. Stable isotope studies using ${ }^{58} \mathrm{Fe}$ demonstrated that the mucosal effect was also seen in man $24 \mathrm{~h}$ after the administration of a placebo or a $50 \mathrm{mg} \mathrm{Fe}$ load, the mean absorption from a $10 \mathrm{mg}$ dose of $\mathrm{Fe}$ being reduced by approximately $29 \%$ after the Fe load (Fairweather-Tait \& Minski, 1986). This points to the necessity of strict dietary control during Fe absorption studies, to eliminate bias in the results, and indicates that lack of such control may be partly responsible for the large variation in absorption measured in human subjects of apparently similar status.

Results from other studies suggest that there are adaptive physiological mechanisms, other than the response to low status, which allow an increased efficiency of Fe (Fairweather-Tait, 1986) and $\mathrm{Zn}$ (Jackson et al. 1984) absorption following consumption of low-mineral diets. For example, the dietary intake of $\mathrm{Fe}$ in Gambian men is not well documented but a qualitative assessment indicates that their diet is far from adequate with respect to many of the trace minerals (McCrae \& Paul, 1979). They consume little meat, an important source of $\mathrm{Fe}$ and $\mathrm{Zn}$, and eat foods containing high levels of known inhibitors of mineral absorption, such as phytate and tannins. However, the prevalence of overt mineral deficiency is not as high as might be expected. For example, of 276 men who were screened for Fe status, only $18 \%$ had a haemoglobin $(\mathrm{Hb})$ of less than $130 \mathrm{~g} /$ (Powers $e t$ al. 1983). Using a stable-isotope technique, described by Fairweather-Tait \& Minski (1986), it was shown that Gambian men absorbed Fe almost twice as efficiently as non-anaemic men from the UK, from both a test dose of $\mathrm{FeSO}_{4}$ and a typical Gambian meal of rice and durango (groundnut paste, tomato paste, chillies and onion) (Fairweather-Tait, 1986; Fairweather-Tait et al. 1987). As previously discussed, Fe deficiency has a marked effect on Fe absorption, but from the measurements of $\mathrm{Fe}$ status that were made on the Gambian men (Hb and free erythrocyte protoporphyrin (FEP)) it seems unlikely that they were depleted of $\mathrm{Fe}$. It was not possible in this particular study to measure serum ferritin levels in the Gambian men to assess Fe stores, but values from another study carried out by colleagues at the Dunn Nutrition Unit showed that amongst eighty-eight men with $\mathrm{Hb}$ levels greater than $128 \mathrm{~g} / \mathrm{l}$, the mean plasma ferritin concentration was $31 \mu \mathrm{g} / \mathrm{l}$ and $\mathrm{Hb} 135 \mathrm{~g} / \mathrm{l}$ (Powers et al. 1983). These values were similar to those obtained for the UK men, which indicates that the enhancement of Fe absorption in the Gambian men was not due to an impaired Fe status. There are several possibilities to be considered as to the nature of this difference between the two groups of subjects. It may be that the Gambian men have an innately higher capacity for $\mathrm{Fe}$ absorption, or that they have been able to permanently adapt to long-term consumption 
of a poor-quality Fe diet. At present, it seems more likely that the continuously low level of exposure of the mucosal cells to Fe has raised their efficiency of absorption on a day-to-day basis, similar to situations seen in rats (Fairweather-Tait \& Wright, 1984). However, the first two possibilities cannot be discounted without further investigation of the phenomenon.

A very clear indication of the ability of animals to adapt to low mineral intakes is given by the rapidity with which laboratory rodents can reduce whole-body ${ }^{65} \mathrm{Zn}$ turnover in response to suboptimal dietary $\mathrm{Zn}$. In the following study ${ }^{65} \mathrm{Zn}(1 \mu \mathrm{Ci}$ in $0 \cdot 1 \mathrm{ml}$ saline $(9 \mathrm{~g}$ sodium chloride $/$ )) was administered subcutaneously to 4-5-week-old mice (C57Bl/Ks strain), after which the exact radioactive dose was measured by counting in a smallanimal whole-body counter (Nuclear Enterprises NE8112). The mice were then given a semi-synthetic diet containing either $1 \mathrm{mg} \mathrm{Zn/kg}$ or $54 \mathrm{mg} \mathrm{Zn/kg}$ and allowed to feed ad lib. Radioactivity was counted over a 4-week period and the results expressed as log $\%{ }^{65} \mathrm{Zn}$ retention in order to obtain an estimate of the rate of loss of ${ }^{65} \mathrm{Zn}$ from the body. The curves show that there was a marked reduction in the rate of ${ }^{65} \mathrm{Zn}$ turnover almost immediately after the introduction of the low-Zn diet (Fig. 2), as also demonstrated in rats (Fairweather-Tait et al. 1985b). It is probable that this effect is the result of a dramatic decrease in $\mathrm{Zn}$ secretion into the gut lumen in order to reduce $\mathrm{Zn}$ loss from the body, thereby conserving it for metabolic function (Methfessel \& Spencer, 1973).

This ability to reduce $\mathrm{Zn}$ loss from the body appears, however, to be partly dependent on the physiological state of the individual. This was demonstrated in a similar experiment where ${ }^{65} \mathrm{Zn}$ turnover in genetically diabetic mice $(d b / d b)$, originating from the $\mathrm{C} 57 \mathrm{Bl} / \mathrm{Ks}$ strain, was studied. These mice exhibit metabolic disturbances resembling those of maturity-onset diabetes in man (Coleman \& Hummel, 1967). They have a marked tendency to obesity, high fasting blood sugar concentration, insulin resistance, glucosuria polydipsia, polyuria and hyperphagia. It was found that the whole-body ${ }^{65} \mathrm{Zn}$ turnover of diabetic and non-diabetic mice given a $\mathrm{Zn}$-supplemented diet was similar, but diabetic animals given a low-Zn diet had a significantly increased rate of ${ }^{65} \mathrm{Zn}$ loss from the body compared with non-diabetic mice given a similar diet (Fig. 2). This raises several points in relation to the utilization of $\mathrm{Zn}$ in these diabetic models and, more generally, in relation to the effects of physiological state on the metabolic availability of minerals. Measurement of food intake in these groups of mice showed that both the low- $\mathrm{Zn}$ and $\mathrm{Zn}$-supplemented $d b / d b$ mice consumed significantly more food than the controls over a $27 \mathrm{~d}$ period, and that the $\mathrm{db} / \mathrm{d} b$ mice given a low- $\mathrm{Zn}$ diet consumed significantly more food than the $\mathrm{Zn}$-supplemented $d b / d b$ mice over the same period (food intakes (g): $d b / d b$ low-Zn 130 (SE 2), Zn-supplemented 121 (SE 2), C57Bl/Ks low-Zn 94 (SE 2), Zn supplemented 84 (SE 2)). Dietary Zn depletion, therefore, did not affect the characteristic hyperphagia of the diabetic animals and, in fact, resulted in increased food intake. This is the reverse of the rapid reduction in food consumption normally observed in animals fed on a $\mathrm{Zn}$-deficient diet (Mills et al. 1969). It might be expected that since the daily $\mathrm{Zn}$ intake was considerably higher in the $\mathrm{Zn}$-supplemented $d b / d b$ mice than the controls, and that the amount of ${ }^{65} \mathrm{Zn}$ retained by the body is normally dependent on the amount of $\mathrm{Zn}$ consumed (Huber \& Gershoff, 1970), the diabetic animals would have an increased rate of ${ }^{65} \mathrm{Zn}$ turnover. The fact that this did not occur demonstrates that a portion of their dietary $\mathrm{Zn}$ did not exchange with the endogenous labelled $\mathrm{Zn}$. It is unlikely that these diabetic animals were able to reduce $\mathrm{Zn}$ excretion as, like many human diabetics, they have been found to have excessive loss of $\mathrm{Zn}$ in the urine (Kinlaw et al. 1983; Levine et al. 1983). The remaining possibility is that they have impaired $\mathrm{Zn}$ absorption. Oral $\mathrm{Zn}$ tolerance testing of human type II diabetic subjects also suggests that this form of diabetes is associated with the malabsorption of Zn (Kinlaw et al. 1983). 


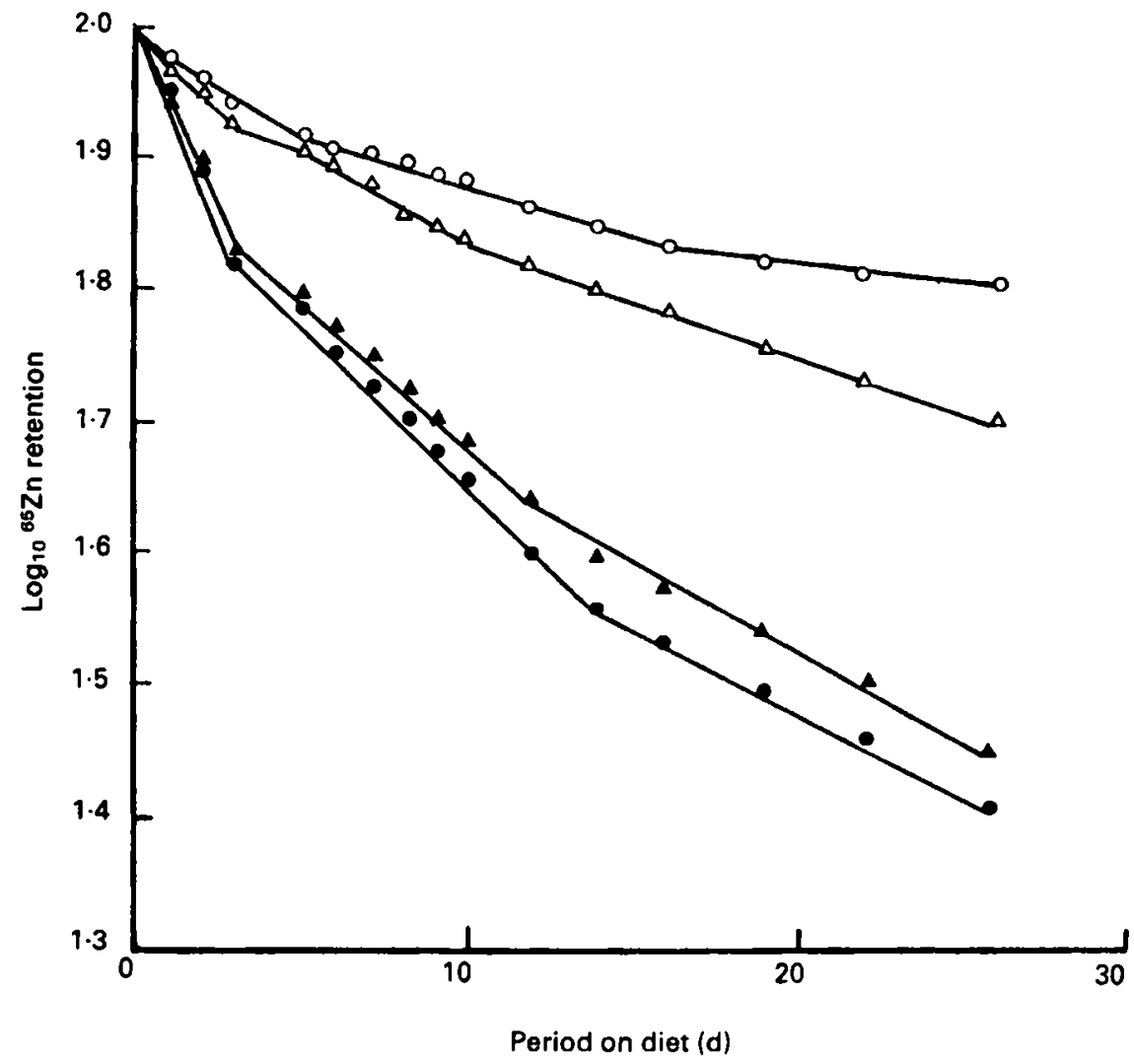

Fig. 2. ${ }^{65} \mathrm{Zn}$ retention over $26 \mathrm{~d}$ (proportion of original amount present on day 0 ; values expressed as $\log _{10}$ ) by diabetic $(d b / d b)$ or normal (C57Bl/Ks strain) mice given $37 \mathrm{kBq}{ }^{65} \mathrm{Zn}$ subcutaneously: $(\Theta), \mathrm{C} 7 \mathrm{Bl} / \mathrm{Ks}$, $\mathrm{Zn}$-supplemented diet; (O), C57BV/Ks, low-Zn diet: $(\boldsymbol{\Lambda}), d b / d b, \mathrm{Zn}_{\mathrm{n}}$-supplemented diet; $(\Delta), d b / d b$, low-Zn diet.

There was a significantly increased rate of whole-body $\mathrm{Zn}$ loss from the $d b / d b$ mice given a low-Zn diet compared with their non-diabetic counterparts. Even if the efficiency of $\mathrm{Zn}$ absorption had been similar between these two groups, it is unlikely that the $38 \%$ increase in consumption of a very low $\mathrm{Zn}$ diet by the diabetic mice would lead to a $65 \%$ increase in ${ }^{65} \mathrm{Zn}$ loss from the body, since these animals would probably have been in negative balance. The study shows, therefore, that these diabetic mice are unable to adapt to a period of dietary $\mathrm{Zn}$ restriction to the same extent as the normal animal, and that the value for $\mathrm{Zn}$ availability from the diet would probably be markedly different for diabetic and non-diabetic subjects. It also underlines the importance of considering the potential effects of physiological state on the metabolic availability of minerals, particularly when the diet may be suboptimal with respect to that mineral.

In view of all the known, and as yet undocumented, factors involved in the regulation of mineral availability, it may appear that a complete understanding of this area of nutrition is a far-reaching goal. However, continuing research in this field is producing increasing insight into the dietary and physiological variables that influence mineral nutrition and will undoubtedly result in an improvement in predictions of mineral availability. 


\section{REFERENCES}

Black, A. E., Wiles, S. J. \& Paul, A. A. (1986). British Journal of Nutrition 56, 59-72.

Bothwell, T. H., Pirzio-Biroli, G. \& Finch, C. A. (1958). Journal of Laboratory and Clinical Medicine 51, 24-36.

Casey, C. E. \& Hambidge, K. M. (1980). In Advances in Nutritional Research vol. 3, pp. 23-63 [H. H. Draper, editor]. New York: Plenum Press.

Coleman, D. L. \& Hummel, K. P. (1967). Diabetologia 3, 238-248.

Cooke, J. D., Layrisse, M. \& Finch, C. A. (1969). Blood 33, 421-429.

Cooke, J. D., Lipschitz, D. A., Miles, L. E. M. \& Finch, C. A. (1974). American Journal of Nutrition 27, $681-687$.

Department of Health and Social Security (1979). Recommended Daily Amounts of Food, Energy and Nutrients for Groups of People in the United Kingdom. Reports on Health and Social Subjects no. 15. London: H.M. Stationery Office.

Fairweather-Tait, S. J. (1986). Proceedings of the XIIth International Congress of Nutrition, pp. 524-526 [T. G. Taylor and N. K. Jenkins, editors]. London: John Libbey.

Fairweather-Tait, S. J. (1987). Nutrition Research 7, 319-325.

Fairweather-Tait, S. J. \& Minski, M. J. (1986). British Journal of Nutrition 55, 279-285.

Fairweather-Tait, S. J., Minski, M. J. \& Singh, J. (1987). American Journal of Clinical Nutrition 46, 844-848.

Fairweather-Tait, S. J., Swindell, T. E. \& Wright. A. J. A. (1985a). British Journal of Nutrition 54, 70-86.

Fairweather-Tait, S. J. \& Symss, L. L. (1986). Proceedings of the Nutrition Society 45, 41 A.

Fairweather-Tait, S. J., Symss, L. L., Smith, A. C. \& Johnson, I. T. (1987). Journal of the Science of Food and Agriculture 39, 341-348.

Fairweather-Tait, S. J. \& Wright, A. J. A. (1984). British Journal of Nutrition 51, 185-191.

Fairweather-Tait, S. J. \& Wright, A. J. A. (1986). Toxicology and Environmental Chemistry 13, 223-228.

Fairweather-Tait, S. J., Wright, A. J. A., Cooke, J. \& Franklin, J. (1985b). British Journal of Nutrition 54, $401-413$.

Gillooly, M., Bothwell, T. H., Torrance, J. D., MacPhail, A. P., Derman, D. P., Bexwoda, W. R., Mill, W., Charlton, R. W. \& Mayet F. (1983). British Journal of Nutrition 49, 33I-342.

Gillooly, M., Torrance, J. D., Bothwell, T. H., MacPhail, A. P., Derman, D., Mills, W. \& Mayet, F. (1984). American Journal of Clinical Nutrition 40, 522-527.

Gopalan, C., Rama Sastri, B. V. \& Balasubramanian, S. C. (1984). Nutritive Value of Indian Foods. Hyderabad: National Institute of Nutrition.

Hallberg, L., Brune, M. \& Rossander, L. (1986). Human Nutrition:Applied Nutrition 40A, 97-113.

Hazell, T. (1985). World Review of Nutrition and Dietetics 46, 1-123.

Hazell, T. \& Johnson, I. T. (1987a). British Journal of Nutrition 57, 223-233.

Hazell, T. \& Johnson, I. T. (1987b). Journal of the Science of Food and Agriculture 38, 73-82.

Huber, A. M. \& Gershoff, S. N. (1970). Journal of Nutrition 100, 949-954.

Jackson, M. J., Jones, D. A., Edwards, R. H. T., Swainbank, I. G. \& Coleman, M. L. (1984). British Journal of Nutrition 51, 199-208.

Jacobs, P., Bothwell, T. H. \& Charlton. R. W. (1964). Journal of Applied Physiology 19, 187-188.

Kinlaw, W. B., Levine, A. S., Morley, J. F., Silvas, S. E. \& McClain, C. J. (1983). American Journal of Medicine 75, 273-277.

Levine, A. S., McClain, C. J., Handwerger, B. S., Brown, D. M. \& Morley, J. E. (1983). American Journal of Clinical Nutrition 37, 382-386.

Linko, P., Colonna, P. \& Mercier, C. (1981). In Advances in Cereal Science and Technology, vol. 4, pp. 145-223 [Y. Pomeranz, editor]. St Paul, MN: American Association of Cereal Chemists.

McCrae, J. E. \& Paul, A. A. (1979). Foods of Rural Gambia. London: Medical Research Council.

Methfessel, A. H. \& Spencer, H. (1973). Journal of Applied Physiology 34, $63-67$.

Miller, D. D., Schricker, B. R., Rasissem, R. R. \& Van Campen, D. (1981). American Journal of Clinical Nutrition 34, 2248-2256.

Mills, C. F., Quaterman, J., Chesters, J. K., Williams, R. B. \& Dalgarno, A. C. (1969). American Journal of Clinical Nutrition 22, 1240-1249.

National Research Council (1980). Recommended Dietary Allowances, 9th revised ed. Washington, DC: National Academy of Sciences.

Paul, A. A. \& Southgate, D. A. T. (1978). McCance \& Widdowson's The Composition of Foods, 4th ed. London: H. M. Stationery Office. 
Powers, H. J., Bates, C. J., Prentice, A. M., Lamb, W. H., Jepson, M. \& Bowman, H. (1983). Human Nutrition:Clinical Nutrition 37C, 413-425.

Sandstead, H. H. (1975). Progress in Food \& Nutrition Science 1, 371-391.

Tan, S. P., Wenlock, R. W. \& Buss, D. H. (1985). Second Supplement of McCance \& Widdowson's The Composition of Foods, Immigrant Foods. London: H. M. Stationery Office.

Wiles, S. J., Nettleton, P. A., Black, A. E. \& Paul, A. A. (1980). Journal of Human Nutrition 34, 189-223. 